\title{
A Mathematical Model of Combined Drug Therapy of HIV Infection
}

\author{
DENISE E. KIRSCHNER ${ }^{\mathrm{a}}$ and G. F. WEBB ${ }^{\mathrm{b}, *}$
}

\author{
${ }^{2}$ Department of Microbiology and Immunology, University of Michigan Medical School, Ann Arbor, MI 48109; \\ ${ }^{b}$ Department of Mathematics, Vanderbilt University, Nashville, TN 37240 USA
}

\begin{abstract}
A mathematical model of the HIV infected human immune system is presented. The model consists of a system of ordinary differential equations for the populations of uninfected $\mathrm{CD}^{+}{ }^{+} \mathrm{T}$ cells, infected $\mathrm{CD} 4^{+} \mathrm{T}$ cells and free virus in the blood. The model is constructed, and parameters chosen, so that turnover rates and life spans for these populations agree with clinical data. The model is used to simulate chemotherapy treatment of HIV infection. The simulations are based upon preliminary clinical reports of treatment with combinations of antiviral drugs involving standard reverse transcriptase inhibitors and newly developed protease inhibitors. The models incorporate the appearance of drug-resistant viral strains, which is the key limiting factor in the effectiveness of HIV chemotherapy. The simulations focus upon the timing of treatment initiation.
\end{abstract}

Keywords: HIV, immune system, AIDS, $\mathrm{CD}^{+}{ }^{+} \mathrm{T}$ cells, combined therapy, drug resistance, mathematical model

\section{INTRODUCTION}

The dynamics of the HIV-infected immune system involve the interaction of $\mathrm{CD}^{+} \mathrm{T}$ cells and virus populations. Recent clinical studies (Ho et al., 1995; Wei et al., 1995) have produced new insight into the dynamics of these populations during HIV infection. These studies identified the turnover rates and life spans of both $\mathrm{CD}^{+} \mathrm{T}$ cells and virus by measuring their rate changes in patients subjected to strong antiviral agents. These studies have led to a new conceptual view of the HIV infected immune system as a hyperdynamic process. In this conceptual model, large numbers of $\mathrm{CD}^{+}{ }^{+} \mathrm{T}$ cells and virus are gained or lost each day as the total $\mathrm{CD}^{+}{ }^{+} \mathrm{T}$-cell population slowly depletes over the course of years.

The recent clinical determination of this dynamical information promotes the development of mathematical modeling for the pathology and therapy of HIV infection. The goal of such mathematical models is to assist qualitative understanding of the complex interactions of $\mathrm{CD} 4^{+} \mathrm{T}$ cells and virus at the population level. The model we present here derives

The gesearch reported in this paper was first presented at the year long workshop on Mathematics in Medicine held at the International Centre for Mathematical Sciences, Edinburgh during 1994-1995.

${ }^{*}$ Corresponding Author. 
from our earlier studies (Kirschner and Webb, 1996; $1997 \mathrm{a}$; 1997b) in that it assumes certain forms for the terms in the differential equations representing population interactions. These equations are constructed so that their solutions produce $\mathrm{CD} 4^{+} \mathrm{T}$-cell counts and viral titers, as well as their turnover rates and life spans, consistent with present clinical knowledge of their values before and after treatment.

Our primary goal here is to model recently developed treatment regimens for combined drug therapy of HIV. Recent reports of ongoing clinical trials show improved benefit for combined drug therapy with newly developed protease inhibitors (ritonavir and indinavir) together with standard reverse transcriptase inhibitors (zidovidine), didanosine and delavirdine) (Travis, 1996; Stephenson, 1996). Although final clinical reports are not yet available, preliminary reports indicate that combined therapy yields (1) viral titers falling to $\leq 1 \%$ of pre-treatment values after a few weeks of treatment and (2) $\mathrm{CD}^{+} \mathrm{T}$-cell counts rising by $\geq 100 / \mathrm{mm}^{3}$ (normal CD4 ${ }^{+} \mathrm{T}$-cell counts lie between $800 / \mathrm{mm}^{3}$ and $1200 / \mathrm{mm}^{3}$ in blood plasma). Furthermore, during combined drug therapy, these improved levels are sustained for months.

These results compare very favorably to standard monotherapy treatment with reverse transcriptase inhibitors alone, which typically yield $\mathrm{CD}^{+}{ }^{+} \mathrm{T}$-cell counts increasing by only about $30 / \mathrm{mm}^{3}$, peaking at 3 months and returning to baseline within 1 year (Fischl et al., 1990). With combined therapy, the appearance of resistance virus, which is a key limiting factor in HIV therapy, is apparently forestalled much longer than with monotherapy. It is generally recognized that monotherapy with reverse transcriptase inhibitors alone extends long-term survival by about 1 year (Enger et al., 1996). The extension of long-term survival with combined therapy is not yet known, but is hoped that it will be significantly longer than with monotherapy.

In the simulations we present here, we focus on two key issues in treatment strategy: (1) the time at which treatment is initiated and (2) the time at which drug-resistant virus appears. With standard reverse transcriptase inhibitors, it is generally recognized that early initiation of treatment (when $\mathrm{CD}^{+}{ }^{+} \mathrm{T}$-cell counts are $>500 / \mathrm{mm}^{3}$ ) and late initiation of treatment (when $\mathrm{CD}^{+}{ }^{+} \mathrm{T}$-cell counts are $<200 / \mathrm{mm}^{3}$ ) is less beneficial than initiation of treatment when $\mathrm{CD} 4^{+} \mathrm{T}$-cell counts are between $200 / \mathrm{mm}^{3}$ and $500 / \mathrm{mm}^{3}$. It is also recognized that drug-resistant virus replaces drug-sensitive virus within a few weeks after initiation of treatment (Wei et al., 1995). Our simulations for combined treatment show the same conclusion for the timing of combined drug-treatment initiation, i.e. advantageous starting times occur when $\mathrm{CD} 4^{+} \mathrm{T}$-cell counts are between $200 / \mathrm{mm}^{3}$ and $500 / \mathrm{mm}^{3}$.

Because the time at which resistance appears during combined therapy is not yet clinically established (and is in any case variable), we allow a range of values for the appearance of resistant virus. In all cases, there is an advantage to beginning treatment with middlelevel CD4 ${ }^{+}$T cell counts. Because treatment is limited by the replacement of sensitive virus with resistant virus, the timing of treatment is of major importance in HIV therapy. In future work, the authors will investigate other treatment-strategy issues in combined drug therapy, such as interrupting treatment before the development of resistance and sequencing different drugs rather than combining them.

\section{THE MODEL}

In the equations below, $T(t)$ represents the uninfected $\mathrm{CD}^{+} \mathrm{T}$-cell population at time $t, T_{\mathrm{s}}(t)$ represents the drug-sensitive infected $\mathrm{CD} 4^{+} \mathrm{T}$-cell population at time $t, T_{\mathrm{r}}(t)$ represents the drug-resistant infected $\mathrm{CD} 4^{+} \mathrm{T}$-cell population at time, $V_{\mathrm{s}}(t)$ represents the drug-sensitive virus population at time $t, V_{\mathrm{r}}(t)$ represents the drug-resistant virus population at time $t$ and $V(t)=V_{\mathrm{s}}(t)+V_{\mathrm{r}}(t)$ represents the total virus population at time $t$. All these populations are measured in the blood plasma, which constitutes only $2 \%$ of their total, the rest residing in the lymphoreticular tissue. The equations for the model without treatment are as follows:

$$
\begin{aligned}
T^{\prime}(t)= & S(t)-\mu_{T} T(t)+\frac{p T(t) V_{\mathrm{s}}(t)}{\left(C+V_{\mathrm{s}}(t)\right)} \\
& -k_{\mathrm{s}} V_{\mathrm{s}}(t) T(t)
\end{aligned}
$$




$$
\begin{aligned}
F_{\mathrm{s}}^{\prime}(t)= & k_{\mathrm{s}} V_{\mathrm{s}}(t) T(t)-\mu_{T_{\mathrm{i}}} T_{\mathrm{s}}(t) \\
& -\frac{p_{\mathrm{i}} T_{\mathrm{s}}(t) V_{\mathrm{s}}(t)}{\left(C_{\mathrm{i}}+V_{\mathrm{s}}(t)\right)} \\
V_{\mathrm{s}}^{\prime}(t)= & N p_{\mathrm{i}} T_{\mathrm{s}}(t) \frac{V_{\mathrm{s}}(t)}{\left(C_{\mathrm{i}}+V_{\mathrm{s}}(t)\right)} \\
& -k_{\nu} T(t) V_{\mathrm{s}}(t)+\frac{G_{\mathrm{s}} V_{\mathrm{s}}(t)}{\left(B+V_{\mathrm{s}}(t)\right)}
\end{aligned}
$$

In equation (1) $S(t)$ represents the source of uninfected $\mathrm{CD} 4^{+} \mathrm{T}$ cells from the thymus or other compartments. It is assumed that there is a degeneration of this isource during the course of HIV infection from a normal input of $10 / \mathrm{mm}^{3}$ per day to $3 / \mathrm{mm}^{3}$ per day: Accordingly, we take

$$
S(t)=10.0-7.0 \frac{V(t)}{\left(B_{\mathrm{s}}+V(t)\right)},
$$

where $B_{\mathrm{s}}$ is a saturation constant. In equation (1) $\mu_{T} T(t)$ is the mortality rate of uninfected $\mathrm{CD} 4^{+}$ $\mathrm{T}$ cells (which we assume live about 100 days), $p$ is a proliferation rate mediating the gain of $\mathrm{CD}^{+}+\mathrm{T}$ cells due to the immune response term $\left[p T(t) V_{\mathrm{s}}(t)\right] /\left[\left(C+V_{\mathrm{s}}(t)\right)\right](C$ is a saturation constant and $k_{s}$ is the infection rate of $\mathrm{CD} 4^{+} \mathrm{T}$ cells by virus; it is assumed that the rate of infection is governed by the mass action term $\left.k_{\mathrm{s}} V_{\mathrm{s}}(t) T(t)\right)$.

In equation (2) there is a gain term $k_{\mathrm{s}} V_{\mathrm{s}}(t) T(t)$ of $\mathrm{CD}^{+} \mathrm{T}$ cells infected by drug-sensitive virus, a loss term $\mu_{T} T_{\mathrm{s}}(t)$ due to the mortality of these cells (we assume that infected CD4 ${ }^{+} \mathrm{T}$ cells live about 2 days) and a $1 \phi \mathrm{ss}$ term $\left[p_{\mathrm{i}} T_{\mathrm{s}}(t) V_{\mathrm{s}}(t)\right] /\left[C_{\mathrm{i}}+V_{\mathrm{s}}(t)\right]$ due to their bursting caused by invading virus ( $p_{\mathrm{i}}$ is a proliferation constant and $C_{\mathrm{i}}$ is a saturation constant).

In equation (3) the virus population is increased by the bursting term $\left[N p_{\mathrm{i}} T_{\mathrm{s}}(t) V_{\mathrm{s}}(t)\right] /\left[C_{\mathrm{i}}+V_{\mathrm{s}}(t)\right]$ (where we take $N=10$ as the number of viable virions produced in each bursting). In equation (3) the virus population is decreased by the immune response term $k_{v} T(t) V_{\mathrm{s}}(t)$ (we assume that $\mathrm{CD} 4^{+}$ $\mathrm{T}$ cells are in $1: 2$ proportion with $\mathrm{CD}^{+} \mathrm{T}$ cells, which are responsible for actual elimination of the virus). In equation (3) there is an external input of virus from compartments outside the blood (spleen, lymph nodes, etc.), which is represented by the term $\left[G_{\mathrm{s}} V_{\mathrm{s}}(t)\right] /\left[B+V_{\mathrm{s}}(t)\right]$. This external input exerts a major influence upon the virus production and the overall course of the disease. This is because 98\% of all $\mathrm{T}$ cells, and hence viral production, are in these other compartments (Lafeuillade et al., 1996). As the parameter $G_{\mathrm{s}}$ increases, the qualitative behavior of the system changes from the existence of a stable uninfected steady state (disease-free state), to the existence of a stable infected steady state (latency) and finally to the collapse of the $\mathrm{CD} 4^{+} \mathrm{T}$ cell population (progression to AIDS). These three types of behavior are illustrated in Figure 1. In each case, it is assumed that the initial population values are $T(0)=1000.0, T_{\mathrm{s}}(0)=0.0$ and $V_{\mathrm{s}}(0)=10.0$.

In the treatment simulations presented here we assume that treatment starts at some time $t_{0}$ with initial values $T\left(t_{0}\right), T_{\mathrm{s}}\left(t_{0}\right)$ and $V_{\mathrm{s}}\left(t_{0}\right)$ obtained from the equations above, and with no resistant strain, namely $T_{\mathrm{r}}\left(t_{0}\right)=0.0$ and $V_{\mathrm{r}}\left(t_{0}\right)=0.0$. The value of $G_{\mathrm{s}}$ is at a level that results in the progression to AIDS. We assume that drug-resistant virus appears at a time $t_{\mathrm{r}}>t_{0}$. The equations for the model with treatment are as follows:

$$
\begin{aligned}
T^{\prime}(t)= & S_{0}(t)-\mu_{T} T(t)+\frac{p T(t) V(t)}{(C+V(t))} \\
& -\left(\mu k_{\mathrm{s}} V_{\mathrm{s}}(t)+k_{\mathrm{r}} V_{\mathrm{r}}(t)\right) T(t) \\
T_{\mathrm{s}}^{\prime}(t)= & \mu k_{\mathrm{s}} V_{\mathrm{s}}(t) T(t)-\mu_{T_{\mathrm{i}}} T_{\mathrm{s}}(t) \\
& -\frac{p_{\mathrm{i}} T_{\mathrm{s}}(t) V(t)}{C_{\mathrm{i}}+V(t)} \\
T_{\mathrm{r}}^{\prime}(t)= & k_{\mathrm{r}} V_{\mathrm{r}}(t) T(t)-\mu_{T_{\mathrm{i}}} T_{\mathrm{r}}(t) \\
& -\frac{p_{\mathrm{i}} T_{\mathrm{r}}(t) V(t)}{C_{\mathrm{i}}+V(t)} \\
V_{\mathrm{s}}^{\prime}(t)= & \frac{\rho q(t) N p_{\mathrm{i}} T_{\mathrm{s}}(t) V(t)}{C_{\mathrm{i}}+V(t)} \\
& +\frac{(1-q(t)) N p_{\mathrm{i}} T_{\mathrm{r}}(t) V(t)}{C_{\mathrm{i}}+V(t)} \\
& -k_{\mathrm{v}} T(t) V_{\mathrm{s}}(t)+\eta \frac{G_{\mathrm{s}} V_{\mathrm{s}}(t)}{B+V(t)} \\
V_{\mathrm{r}}^{\prime}(t)= & \frac{q(t) N p_{\mathrm{i}} T_{\mathrm{r}}(t) V(t)}{C_{\mathrm{i}}+V(t)}+\frac{(1-q(t)) N p_{\mathrm{i}} T_{\mathrm{s}}(t) V(t)}{C_{\mathrm{i}}+V(t)} \\
& -k_{v} T(t) V_{\mathrm{r}}(t)+\frac{G_{\mathrm{r}} V_{\mathrm{r}}(t)}{B+V(t)} \\
&
\end{aligned}
$$



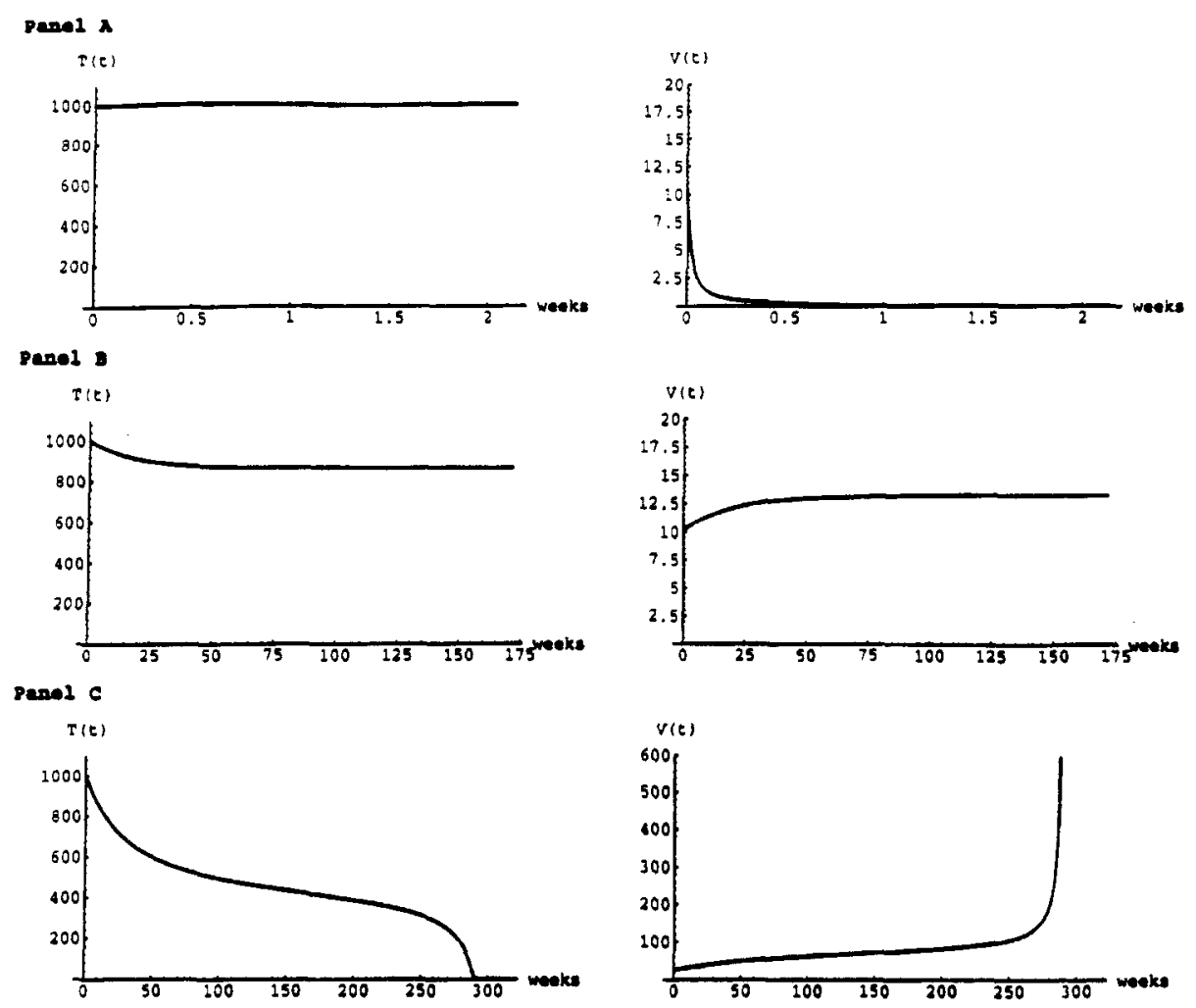

FIGURE $1 \mathrm{CD}^{+} \mathrm{T}$-cell counts and viral titers without treatment. Panel $\mathbf{1 A}=$ uninfected steady state $\left(G_{\mathrm{s}}=80.0\right)$, Panel $\mathbf{1 B}=$ infected steady state $\left(G_{\mathrm{s}}=180.0\right)$, Panel $\mathrm{C}=$ progression to AIDS $\left(G_{\mathrm{s}}=330.0\right)$.

In equations (4)-(8), treatment is modeled as a constant reduction in various viral rates during the time of treatment (we do not model drug pharmacokinetics or metabolic variations). During treatment, the loss of uninfected $\mathrm{CD}^{+} \mathrm{T}$ cells in equation (4) and the consequent gain of sensitive virus-infected $\mathrm{CD}_{4}^{+} \mathrm{T}$ cells in equation (5) are multiplied by a treatment parameter $\mu<1.0$. This effect of treatment may be interpreted as the effect of a reverse transcriptase inhibitor, which reduces infection of new cells, but does not block production of virus from cells already infected and past the stage at which reverse transcription occurs (Nowak and Bonhoeffer, 1995).

During treatment, the term corresponding to the production of sensitive virus due to bursting in equation (7) is multiplied by a treatment parameter $\rho<1.0$. This effect of treatment may be interpreted as the effect of a protease inhibitor, which acts later in the cell interphase of the virus life cycle to block the production of new virus particles. During treatment, the external sensitive virus input term in equation (7) is multiplied by a treatment parameter $\eta<1.0$. This effect of treatment further inhibits the production of new sensitive virus, since treatment represses replication of virus that enters the blood from external compartments.

When treatment begins, we assume that the source term of $\mathrm{CD}^{+} \mathrm{T}$ cells in equation (4) has the value $S_{0}(t)=\operatorname{minimum}\left\{S(t), S\left(t_{0}\right)\right\}$, where $t_{0}$ is the time at which treatment is initiated. This assumption means that the external input of $\mathrm{CD}^{+} \mathrm{T}$ cells does not increase once treatment begins. We thus assume that there is no direct enhancement of $\mathrm{CD}^{+} \mathrm{T}$ cell production or recruitment due to treatment, but only an indirect effect due to a reduced rate of their infection. This assumption is controversial, since it has been advocated that the increase in $\mathrm{CD}_{4}^{+} \mathrm{T}$ cells induced by antiviral treatment is a direct result of $\mathrm{CD}^{+}$T-cell production which is stimulated in 
the bone marrow (Agur et al., 1995) or by the direct release of $\mathrm{CD}^{+}$lymphocytes from trapping in the lymphoidal tissue (Sprent and Tough, 1995).

In our model of treatment, we assume that there is a known time $t_{\mathrm{r}}$ (which can vary) at which resistant virus appears. Before $t_{\mathrm{r}}$, there is no significant level $\phi$ f resistant virus present. After $t_{\mathrm{r}}$ there is a proportion $q<1.0$ of sensitive virus produced that remain faithful to the sensitive type and a proportion $1.0-q$ that mutate to the resistant type. This phenomenon is incorporated into the equation for the sensitive virus (7) (analogous relationships hold for the equation for the resistant virus, equation (8)). In both of these equations, $q(t)=1.0$ for $t<t_{\mathrm{r}}$ and $q(t)=q$ for $t>t_{\mathrm{r}}$. We assume that the external input constant $G_{\mathrm{r}}$ in equation (8) is slightly less that $G_{\$}$ in equation (7), which means that the wild type (sensitive virus) has an evolutionary advantage over the mutant type (resistant virus). In Table I, we provide a list of parameter values for the models with and without treatment. In Table II, we provide a comparison of various quantitative values of the models and clinical data (model values are computed using average disease state values for $\mathrm{CD} 4^{+} \mathrm{T}$ cells, virus and infected T cells as $T(t)=435 / \mathrm{mm}^{3}$, $V(t)=72 / \mathrm{mm}^{3}$ and $T_{\mathrm{S}}(t)=12 / \mathrm{mm}^{3}$, respectively, at a typical time $t=150$ weeks as in Figure 1, Panel C).

\section{THE SIMULATIONS}

We first provide simulations for the model without treatment, equations (1)-(3). In Figure 1, we show

TABLE I Parameter values for models with and without treatment

\begin{tabular}{ll}
\hline \multicolumn{1}{c}{ Parameters and constants } & \multicolumn{1}{c}{ Values } \\
\hline$\mu_{T}=$ mortality rate of uninfected CD4 ${ }^{+} \mathrm{T}$ cells & $0.01 /$ day \\
$\mu_{T_{\mathrm{i}}}=$ mortality rate of infected CD4 ${ }^{+} \mathrm{T}$ cells & $0.5 / \mathrm{day}$ \\
$k_{\mathrm{s}}=$ rate CD4 ${ }^{+} \mathrm{T}$ cells are infected by sensitive virus & $2.5 \times 10^{-4} \mathrm{~mm}^{3}$ day \\
$k_{\mathrm{r}}=$ rate CD4 ${ }^{+} \mathrm{T}$ cells are infected by resistant virus & $2.5 \times 10^{-4} \mathrm{~mm}^{3}$ day \\
$k_{\nu}=$ rate CD8 ${ }^{+} \mathrm{T}$ cells kill virus & $0.01 / \mathrm{mm}^{3}$ day \\
$p=$ proliferation rate of uninfected CD4 ${ }^{+} \mathrm{T}$ cells & $0.5 / \mathrm{mm}^{3}$ day \\
$p_{\mathrm{i}}=$ proliferation rate of infected CD4 ${ }^{+} \mathrm{T}$ cells & $0.5 / \mathrm{mm}^{3}$ day \\
$G_{\mathrm{s}}=$ rate of input of external sensitive virus to the blood & $330.0 \mathrm{~mm}^{3} /$ day \\
$G_{\mathrm{r}}=$ rate of input of external resistant virus to the blood & $0.9995 \times G_{\mathrm{s}}$ \\
$q=$ probability of mutation & 0.999 \\
$N=$ number of viable virus produced in bursting & 10.0 \\
$C=$ half-saturation constant of uninfected CD4 & $188.0 / \mathrm{mm}^{3}$ \\
$C_{\mathrm{i}}=$ half-saturation colls & $188.0 / \mathrm{mm}^{3}$ \\
$B=$ half-saturation constant of external virus input & $8.0 \mathrm{~mm}^{3}$ \\
$B_{\mathrm{S}}=$ half-saturation constant of CD4 ${ }^{+} \mathrm{T}$-cell source & $55.0 \mathrm{~mm}^{3}$ \\
$\mu=$ treatment parameter & 0.9 \\
$\eta=$ treatment parameter & 0.15 \\
$\rho=$ treatment parameter & 0.05 \\
\hline
\end{tabular}

TABLE II Comparison of quantitative values and clinical data

\begin{tabular}{|c|c|c|}
\hline Parameter & Model values & Clinical data values \\
\hline $\begin{array}{l}\mathrm{CD}^{+}{ }^{+} \mathrm{T} \text {-cell turnover } \\
\text { rate }\end{array}$ & $12 / \mathrm{mm}^{3}$ per day & $\begin{array}{l}7 / \mathrm{mm}^{3} \text { per day (Ho et al., 1995) } \\
8 / \mathrm{mm}^{3} \text { per day (Wei et al., 1995) }\end{array}$ \\
\hline $\begin{array}{l}\text { Plasma virus } \\
\text { turnover rate }\end{array}$ & $300 / \mathrm{mm}^{3}$ per day & $\begin{array}{l}136 / \mathrm{mm}^{3} \text { per day (Ho et al., 1995) } \\
2060 / \mathrm{mm}^{3} \text { per day (Wei et al., 1995) }\end{array}$ \\
\hline $\begin{array}{l}\text { Life span of infected } \\
\mathrm{CD}^{+} \mathrm{T} \text { cell }\end{array}$ & 1.6 days & 1 to 2 days (Coffin, 1995) \\
\hline Life span of virus & 0.23 days & 0.3 day (Perelson et al., 1996) \\
\hline $\begin{array}{l}\text { Percent of } \mathrm{CD}^{+}{ }^{+} \\
\text {T-cells infected }\end{array}$ & $3 \%$ & $5 \%$ (Embretson et al, 1993 ) \\
\hline
\end{tabular}


the qualitative behavior of solutions for three different values of the external viral input parameter $G_{s}$ : Figure 1A - locally stable uninfected steady state, Figure 1B -- locally stable infected steady state and Figure 1C - progression to AIDS. Figure $1 \mathrm{~A}$ demonstrates that the immune system can eradicate the disease, but only if the external viral source is extremely low. Figure 1B demonstrates that a long period of non-progression may ensue, provided that the external input of virus into the blood from other compartments is low. Figure 1C shows a typical gradual decline of the $\mathrm{CD} 4^{+} \mathrm{T}$-cell population for a progressor, when the external input of virus from other compartments is high.

In Figure 2, we provide a typical combined treatment simulation for the model equations (4)-(8).


FIGURE $2 \mathrm{CD}^{+}$T-cell count $(\mathbf{A})$ and viral titer $(\mathbf{B})$ when treatment starts with $T(t)=300 / \mathrm{mm}^{3}$. Dashed curve represents non-treatment progression.


FIGURE $3 \mathrm{CD}^{+}$T-cell count $(\mathbf{A})$ and viral titer $(\mathbf{B})$ when treatment starts with $T(t)=500 /$ mm $^{3}$. Dashed curve represents non-treatment progression. 
COMBINED DRUG THERAPY OF HIV INFECTION

31
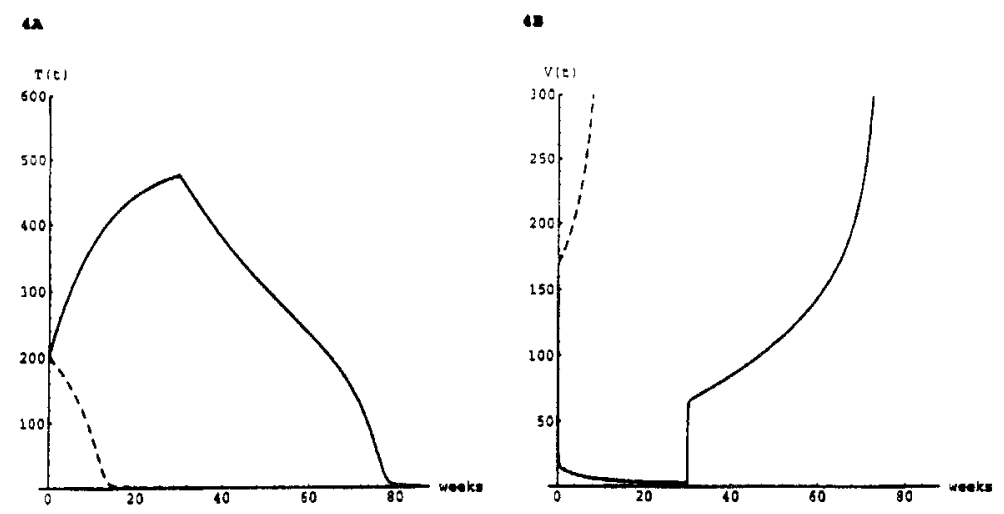

FIGURE $4 \mathrm{CD}^{+}{ }^{+}$T-cell count (A) and viral titer (B) when treatment starts with $T(t)=200 / \mathrm{mm}^{3}$. Dashed curve represents non-treatment progression.
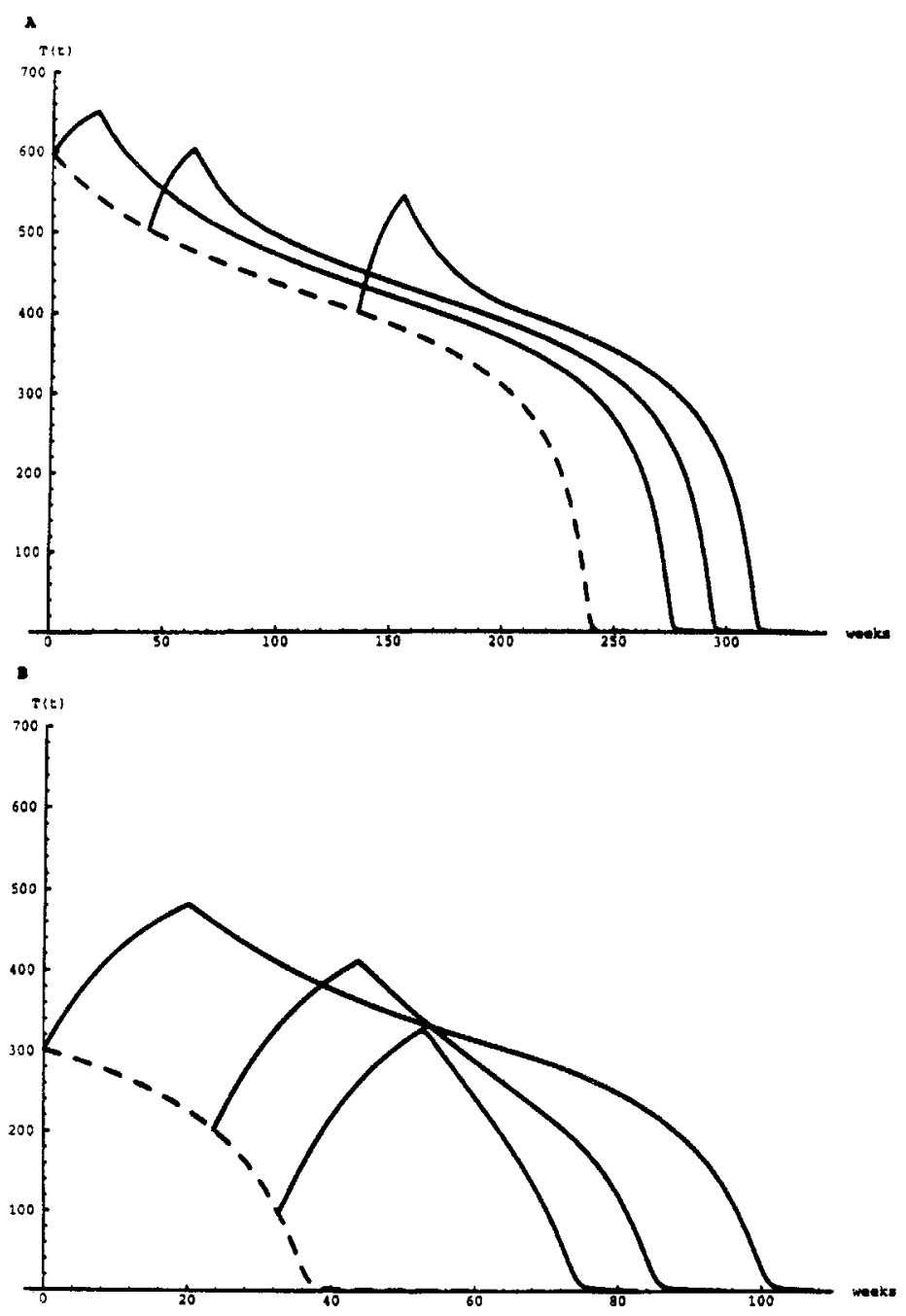

FIGURE 5 Composite CD4 ${ }^{+}$T-cell counts for treatment starting at (A) 600, 500 and $400 / \mathrm{mm}^{3}$ and (B) 300,200 and $100 / \mathrm{mm}^{3}$ with resistance appearing at $t_{\mathrm{r}}=20$ weeks after treatment starts. Dashed curve represents non-treatment progression. 


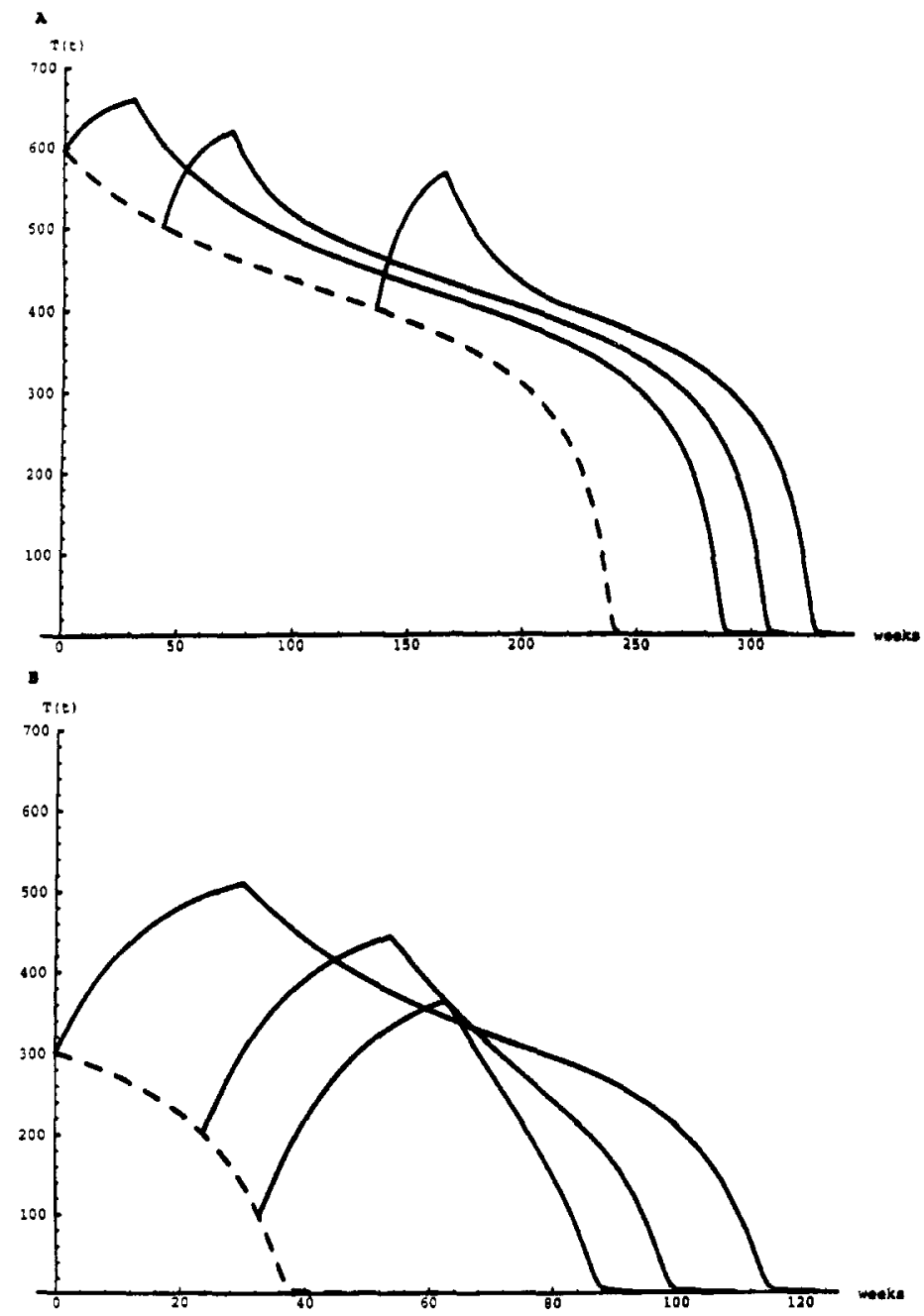

FIGURE 6 Composite CD4 ${ }^{+}$T-cell counts for treatment starting (A) 600,500 and $400 / \mathrm{mm}^{3}$ and (B) 300,200 and 100/mm with $^{3}$ resistance appearing at $t_{\mathrm{r}}=30$ weeks after treatment starts. Dashed curve represents non-treatment progression.

Treatment begins when the $\mathrm{CD}^{+}$T-cell count is $300 / \mathrm{mm}^{3}$ and continues until the $\mathrm{CD}^{+}{ }^{+} \mathrm{T}$-cell population collapses. Resistance appears at $t_{\mathrm{r}}=$ 30 weeks after treatment starts. The dashed curve in Figure $2 \mathrm{~A}$ shows the $\mathrm{CD}^{+}{ }^{+} \mathrm{T}$-cell count without treatment for comparison. The curve in Figure 2B shows the total virus population $V(t)=V_{\mathrm{S}}(t)+$ $V_{\mathrm{r}}(t)$. After the appearance of resistant virus at time $t_{\mathrm{r}}$ the virus is all resistance. The dashed curve in Figure $2 \mathrm{~B}$ shows the sensitive virus population values without treatment. Figures 3 and 4 show similar simulations for $\mathrm{CD}^{+}$T-cell counts at $500 / \mathrm{mm}^{3}$ and
$200 / \mathrm{mm}^{3}$ at treatment initiation $\left(t_{\mathrm{r}}=3\right.$ weeks in both).

The success of treatment here is based on longer survival times equated to $\mathrm{CD} 4^{+} \mathrm{T}$-cell counts, thus we present the following simulations. In Figure 5 we show a composite graph of $\mathrm{CD}^{+} \mathrm{T}$-cell count simulations for treatment starting when counts are 600,500 and $400 / \mathrm{mm}^{3}$ (Figure 5A) and 300, 200 and $100 / \mathrm{mm}^{3}$ (Figure $5 \mathrm{~B}$ ). The time when resistance appears is $t_{\mathrm{r}}=20$ weeks. In Figures 6 and 7 we provide similar composite graphs for resistance appearing at $t_{r}=30$ weeks and $t_{4}=40$ weeks, 

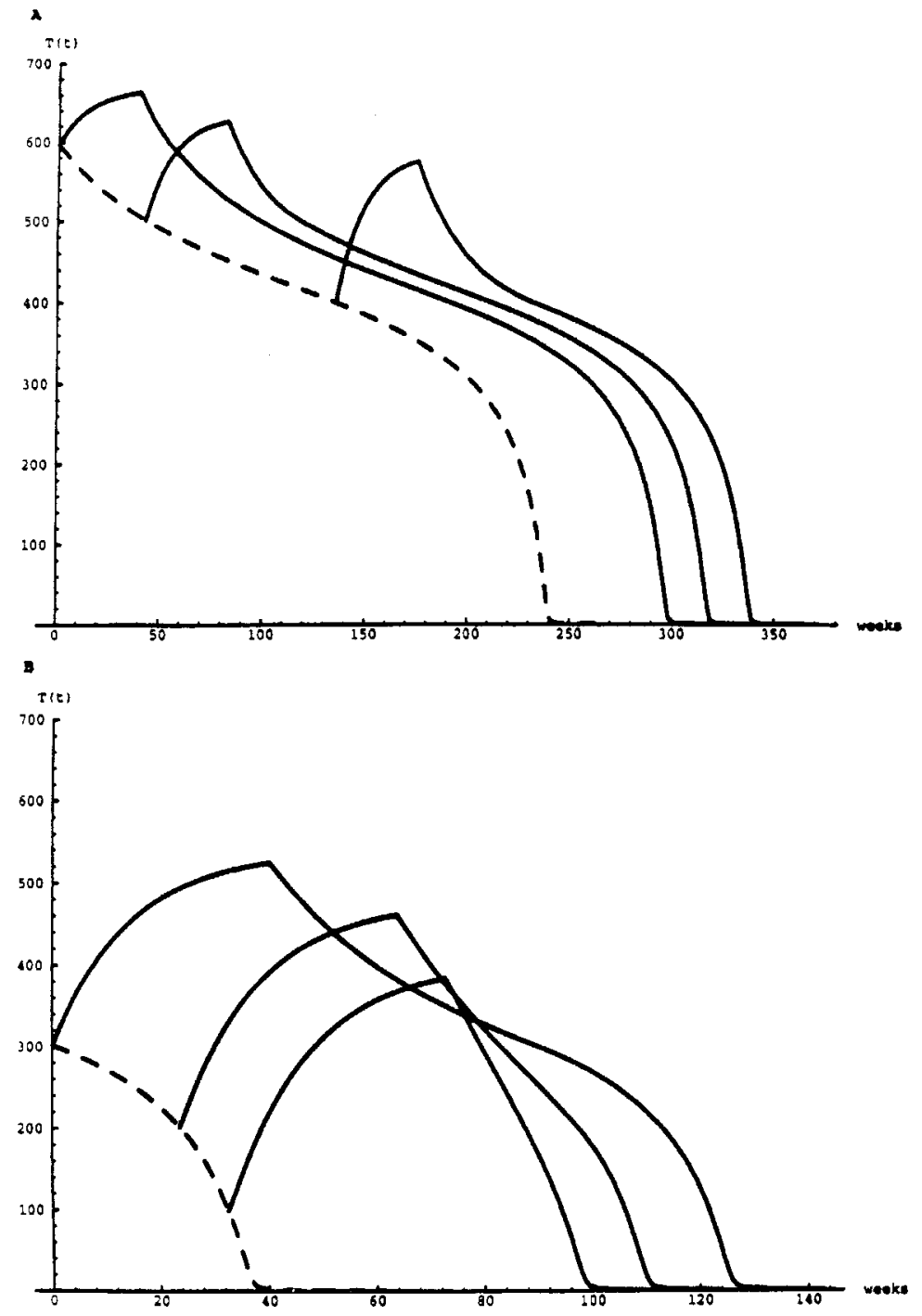

FIGURE 7 Composite CD4 ${ }^{+}$T-cells counts for treatment starting at (A) 600,500 and $400 / \mathrm{mm}^{3}$ and (B) 300, 200 and 100/mm with resisttance appearing at $t_{\mathrm{r}}=40$ weeks after treatment starts. Dashed curve represents non-treatment progression.

respectively. From Figures 5,6 and 7 it appears that the greatest survival benefit occurs if treatment is initiated when $\mathrm{CD}^{+}$T-cell counts are between $300 / \mathrm{mm}^{3}$ and $400 / \mathrm{mm}^{3}$ and this benefit is independent of the time that resistance appears. It is also apparent that long-term survival benefit is not correlated to treatment-induced increases in $\mathrm{CD}^{+} \mathrm{T}$-cell counts, which increase as CD4 ${ }^{+} \mathrm{T}$-cell starting values decrease (this correlation is consistent with data given by Ho et al. (1995)).
The explanation for the advantage of beginning treatment when $\mathrm{CD} 4^{+} \mathrm{T}$-cell counts are at a middle level in these simulations lies in the assumptions of the model. When $\mathrm{CD} 4^{+} \mathrm{T}$-cell counts are high at treatment start, they do not depart as much from baseline values, and consequently return to baseline more quickly when resistance appears. As $\mathrm{CD}^{+}$ T-cell counts become lower, and then treatment is initiated, the return to baseline takes longer and survival length increases. When $\mathrm{CD} 4^{+} \mathrm{T}$-cell counts 
are very low at start of treatment, the population is now overcome more rapidly by the high viral load as resistant virus replaces sensitive virus. In a separate study of the authors (Kirschner and Webb, 1997b), we model resistance in a different way, and the results indicate that early, strong treatment yields the most benefit. In these simulations, the deteriorating source of $\mathrm{CD} 4^{+} \mathrm{T}$-cells is the critical factor in the disadvantage of late initiation of treatment, since there is a much lower input of these cells during treatment $\left(S\left(t_{0}\right)\right.$ is close to the limiting value of $3 / \mathrm{mm}^{3}$ per day).

\section{Acknowledgement}

This work was supported under grant numbers DMS 9596073 and DMS 9631580 of the National Science Foundation.

\section{References}

Agur, Z., Tagliabue, G., Schechter, B. and Ubezio, P. (1995) "AZT effect on bone marrow - a new perspective on the Concorde Trials", J. Biol Sys., 3, 241-251.

Coffin, J. M. (1995). "HIV population Dynamics in vivo: implications fir genetic variation, pathogenesis and therapy", Sci ence 267, 483-489.

Embretson, J. (1993). "Analysis of HIV infected tissues by amplification and in situ hybridization reveals latent and permissive infections at single-cell resolution, Proc, Nat. Acad Sci., 90, 357.

Enger, D., Graham, N., Peng, Y., Chmiel, J. S., Kingsley, L. A. Detels, R. and Munoz. A. (1996). "Survival from early, intermediate, and late stages of HIV infection", J. Amer. Med Assoc., 275, 1329-1334

Fischl. M. A., Richman, D. D., Hansen, N., Collier, A. C. Carey, J. T. and Para, M. F. (1990). "The safety and efficacy of AZT in the treatment of subjects with mildly symptomatic HIV Type I", Ann. Int. Med., 112, 727-737.

Haynes. B. F., Pantaleo. G. and Fauci, A. S. (1996). "Toward an understanding of the correlations of protective immunity to HIV infection". Science, 271, 324-328.

Ho, D. D., Neumann. A. U.. Perelson, A. S., Chen, W., Leonard, J. M. and Markowitz, M. (1995), "Rapid turnover of plasma virions and $\mathrm{CD}^{+}$lymphocytes in HIV-1 infection, Nature, 373, $123-126$.

Kirschner, D. and Perelson. A. (1995). "A model for the immune system response to HIV: AZT treatment studies", In O. Arino. D. Axelrod and M. Kimmel, eds. Mathematical Populations Dynamics. III Theory of Epidemics 1, pp. 295-310 (Wuerz). Winnipeg, Canada.

Kirschner, D. and Webb, G. F. (1996). "A model for treatment strategy in the chemotherapy of AIDS", Bull. Math. Biol., 58(2), 367-390.

Kirschner, D. and Webb, G. F. (1997a). Understanding drug resistance for monotherapy treatment of HIV infection", Bull. Math. Biol., 59(4), 763-785.

Kirschner, D. and Webb, G. F. (1997b). "Qualitative differences in HIV chemotherapy between remission and resistance outcomes", Emerging Infections Diseases, (in press).

Lafeuillade, A., Poggi, C., Profizi, N., Tamalet, C. and Costes, O. (1996). "Human immunodeficiency virus type 1 kinetics in lymph nodes compared with plasma", J. Infect. Dis., 174, 404-407.

McLean, A. and Nowak, N. (1992). "Competition between AZT sensitive and AZT resistant strains of HIV, AID, 6, 71-79.

Nowak, M. A. and Bonhoeffer, S. (1995). "Scientific correspondence", Science 375. 193.

Perelson, A. (1989). "Modeling the interaction of the immune system with HIV". In C. Castillo-Chavez, ed. Mathematical and Statistical Approaches to AIDS Epidemiology, Lectures Notes in Biomathematics 83, Springer-Verlag, New York, pp. 350-370.

Perelson, A., Kirschner, D. E. and De Boer. R. J. (1993), "The Dynamics of HIV infection of $\mathrm{CD}^{+} \mathrm{T}$ cells", Math. Biosciences, 114, $81-125$.

Perelson, A., Neumann, A. U., Markowitz, M., Leonard, J. M. and Ho, D. D (1996). "HIV-1 dynamics in vivo: virion clearance rate, infected cell lifespan, and viral generation Time", Science, 271, 1582-1586.

Sprent, J. and Tough, D. (1995). "Scientific correspondence", Nature 375, 194

Stephenson, J. (1996). "New anti-HIV drugs and treatment strategies buoy AIDS researchers", J. Amer. Med. Assoc., 275. $579-580$.

Travis. J. (1996). "New drugs, New tests, new optimism mark recent AIDS research", Science News, 149, 184-186.

Wei, X., Ghosh, S. K., Taylor, M. E., Johnson, V. A., Emini E. A., Deutsch, P., Lifson, J. D.. Bonhoeffer, S., Nowak, M. A., Hahn, B. H., Saag, M. S. and Shaw, G. M. (1995). "viral dynamics in human immunodeficiency virus type 1 infection", Nature 373, 117-122.

Wein, L. M., Zenios, S. and Nowak, M. A. "Dynamic multidrug therapies for HIV: a control theoretic approach", J. Theo. Biol., (in press) 




The Scientific World Journal
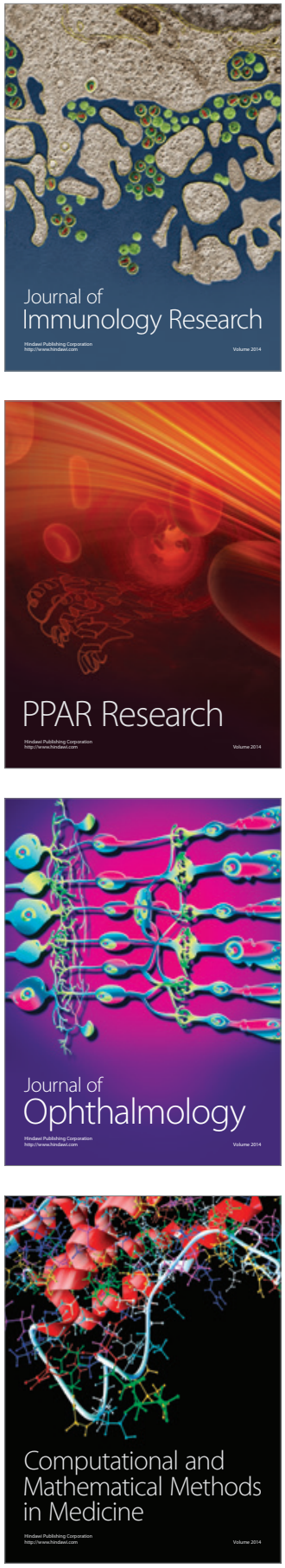

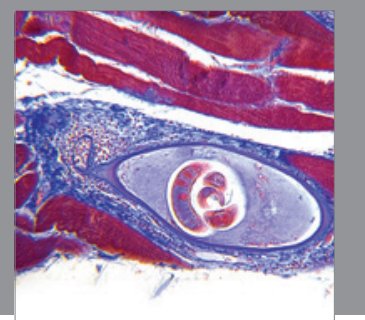

Gastroenterology

Research and Practice
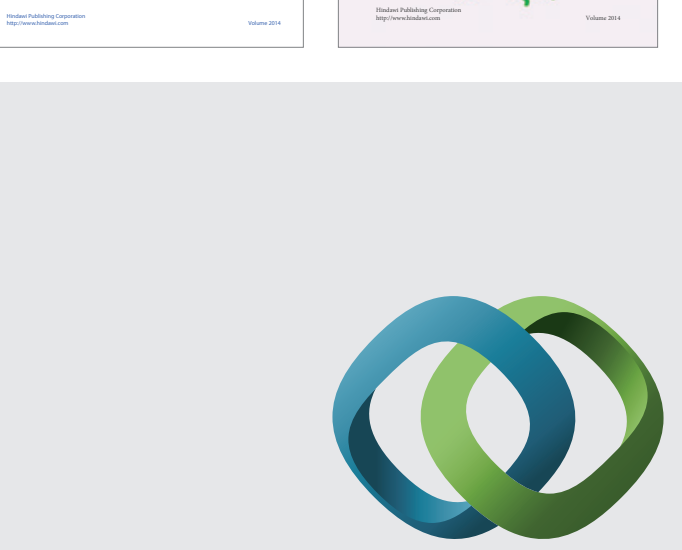

\section{Hindawi}

Submit your manuscripts at

http://www.hindawi.com
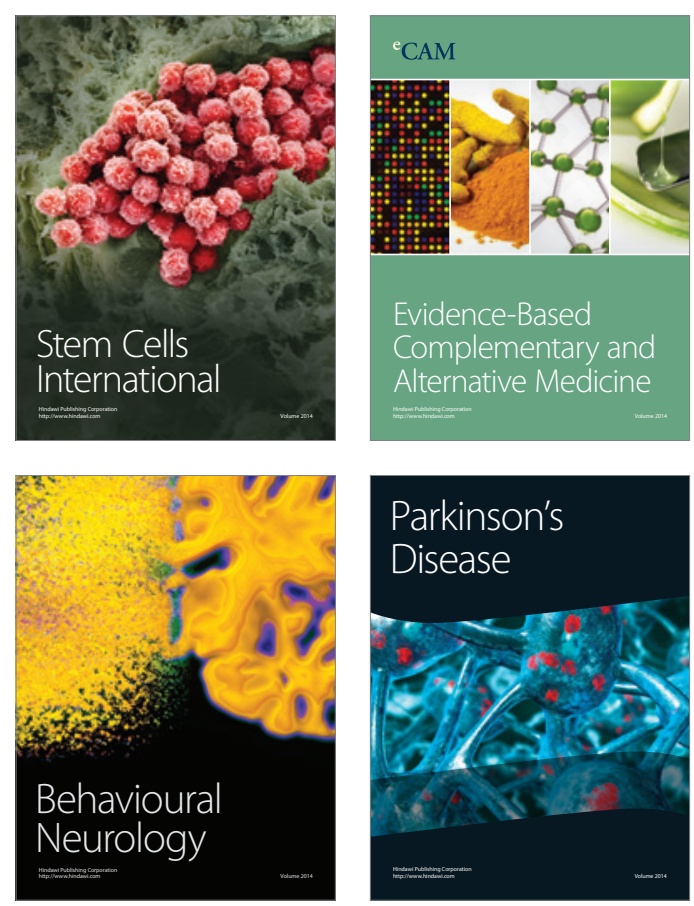

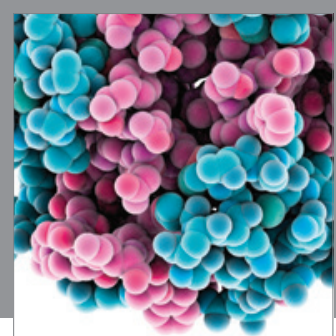

Journal of
Diabetes Research

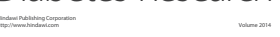

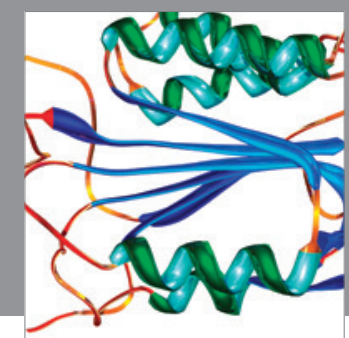

Disease Markers
